\title{
Pelatihan Pengelolaan Laboratorium Dan Penggunaan Alat Peraga IPA Bagi Guru- Guru IPA Di SMP/MTS Se-Kota Bandar Lampung
}

\author{
Training of Laboratory Management And use of Natural Science Teaching Aids \\ For Junior High School Science Teachers in Bandar Lampung
}

Undang Rosidin*, Dina Maulina, Wayan Suane

Pendidikan Fisika, FKIP, Universitas Lampung, E-mail: undangros@yahoo.com

\begin{abstract}
Abstrak
Pembelajaran IPA dan laboratorium tidak dapat dipisahkan keberadaannya secara fungsional. Guru sebagai komponen penting dalam menentukan keberhasilan pendidikan menjadi protokol dalam kegiatan pembelajaran IPA berbasis laboratorium dan pengelolaannya. Tujuan kegiatan pelatihan ini adalah untuk meningkatkan kemampuan guru dalam mengoperasikan alat peraga laboratorium, serta meningkatkan kemampuan guru terhadap teknik pengelalolaan laboratorium dan keterampilan menggunakan alat laboratorium guru. Kegiatan pelatihan ini menerapkan strategi kontekstual, yaitu mengaitkan antara teori dengan praktik yang disampaikan dengan metoda praktik terbimbing yaitu sistem pengajaran yang berorientasi pada pemecahan masalah yang dihadapi mengenai pengelolaan laboratorium. Pelaksanaan kegiatan pelatihan ini bertempat di SMP Negeri 2 Bandar Lampung, dengan subjek kegiatan pelatihan ini adalah 75 orang guru mata pelajaran IPA SMP/MTs se-Kota Bandar Lampung. Hasil kegiatan pelatihan ini menunjukan bahwa ada peningkatan pengetahuan managerial laboratorium, dimana seluruh kemampuan peseta meningkat kecuali bagi para peserta yang tidak mengikuti kegiatan pelatihan hingga akhir. Kemampuan guru dalam menggunakan alat peraga (kit) IPA sudah baik. Hasil penilaian $100 \%$ guru telah mencapai standar ketuntasan yaitu $>70$. Dengan demikian, kegiatan pelatihan dikatagorikan berhasil dalam meningatkan kemampuan guru IPA MTs se-Kota Bandar Lampung tata kelola laboratorium dan penggunaan perangkat/kit IPA serta mampu mengenal fungsi dan kegunaan alat dan bahan praktikum dalam menunjang pembelajaran IPA.
\end{abstract}

Kata kunci: alat peraga IPA, pembelajaran IPA, pengelolaan laboratorium.

\begin{abstract}
Science and laboratory learning is not be separated as functionally tools. The teacher as an important component in determining the success of education becomes a protocol in laboratory-based science learning activities and its management. The purpose of this training activity was to improve the ability of teachers to operate laboratory teaching aids, and to manage laboratory techniques. The method used in this activity was to applying the contextual strategy to linked theory with practice delivered with the guided practice method. There was teaching system oriented towards solving problems encountered regarding laboratory management. The implementation of the training activities took place at SMP Negeri 2 Bandar Lampung, which was held for 4 days (32 hours). The subjects in this training activity were 75 Junior High School Science Teachers in Bandar Lampung. The results of this training activity showed that there was an increase in laboratory managerial knowledge, where all trainees' abilities increased except for participants who did not attend the training activities until the end. The ability of teachers to use science teaching aids (kits) is good. The results of the $100 \%$ assessment of teachers have reached the completeness standard of $\geq 70$. Therefores, the training activities are categorized as successful in reminding the ability of science teachers throughout Bandar Lampung in laboratory management and the use of science devices and being able to recognize the functions and usefulness of practical tools and materials in supporting science learning.
\end{abstract}

Key words: science teaching aids, science learning, laboratory management. 


\section{PENDAHULUAN}

Guru merupakan salah satu komponen penting dalam menentukan keberhasilan pendidikan. Oleh karena itu, pembinaan terhadap guru mutlak diperlukan. Mutu guru secara konsisten menjadi salah satu faktor terpenting dari mutu pendidikan. Lebih lanjut, guru yang bermutu mampu membelajarkan murid secara efektif sesuai dengan kendala sumber daya dan lingkungan (Sudarwan, 2002). Kompetensi professional dan pedagogik menjadi faktor penting seorang guru dalam melaksanakan pembelajaran dan berhasilnya kegiatan pembelajaran (Direktorat Jendral Pendidikan Dasar dan Menengah Umum, 2003). Kemampuan pedagogik adalah kemampuan guru dalam managerial pembelajaran dan hal-hal yang penunjang kegiatan permbelajan. Salah satu kemampuan yang harus dimiliki oleh seorang guru Ilmu Pengetahuan Alam (IPA) adalah kemampuan dalam managerial laboratorium sekolah (Subiantoro, 2010; Sutrisno, 2007). Keberadaan laboratorium disekolah memerlukan perhatian, baik secara fungsional maupun tata kelola yang baik (Suyanta, 2010). Baik perawatan alat-alat, tata kelola tempat dan keamanan pengguna laboratorium (Depdiknas, 2007). Kompetensi profesional adalah kemampuan penguasaan materi pelajaran secara luas dan mendalam. Penguasaan materi secara luas dan mendalam tersebut menyangkut penguasaan penggunaan berbagai alat peraga IPA dalam laboratorium. Penguasaan penggunaan berbagai alat peraga tersebut sangat menunjang proses pembelajaran IPA.

Kemampuan penggunaan berbagai alat peraga IPA merupakan salah satu permasalahan pendidikan di Bandar Lampung adalah kurangnya penguasaan konsep dan penggunaan alat-alat praktikum IPA (Maulina, 2008). Penggunaan alat peraga/ media dalam pembelajaran IPA dapat mewakili suatu fenomena atau suatu peristiwa alam yang sedang dikaji (Daryanto, 2014). Dalam pembelajaran IPA, guru tidak cukup menguasai materi saja, tetapi harus mahir menggunakan alat peraga fisik contohnya alat-alat ukur, dan alat peraga KIT (Kotak Instrumen Terpadu) sehingga materi yang disampaikan akan lebih mudah dipahami oleh siswa (Litasari, Setiati, dan L. Herlina, 2014).

Pelajaran IPA pada tingkat SMP adalah salah satu ilmu yang membahas gejala dan perilaku alam, sepanjang dapat diamati oleh manusia. Cara mengungkapkannya tidak saja kualitatif tetapi juga kuantitatif. Dengan demikian ada empat cara memahami ilmu IPA tersebut. Pertama kejelasan tentang matra atau wadah gejala dimana perilaku alam berlangsung, kedua adalah kejelasan tentang objek yang menjadi fokus bahasan, ketiga yaitu mengenal alat dan media yang akan digunakan untuk menangkap gejala dan prilaku alam tersebut, dan keempat adalah bahasa yang digunakan untuk mengungkap perilaku alam tersebut. Jika salah satu dari keempat komponen tersebut diatas kurang dipahami, akan menyulitkan guru memahami IPA secara utuh (Khamidah dan Aprilia, 2014). Akibatnya pemahaman guru hanya berupa hapalan tanpa mengetahui perilaku alam yang sebenarnya.

Selama ini sangat jarang bahkan hampir tidak pernah diadakan pelatihan tentang pengelolaan tata laboratorium dan penggunaan alat peraga dalam mengajarkan materi IPA sehingga guruguru cenderung menggunakan metode konvensional, seperti metode ceramah (Anonim, 2014). Dalam metode konvensional guru sangat aktif dan siswa pasif. Guru aktif sendirian tanpa melibatkan siswa dalam pembelajaran, semestinya dalam pembelajaran IPA siswa harus dilibatkan, siswa diarahkan melakukan suatu kegiatan untuk memecahkan permasalahanpermasalahan IPA sehingga siswa bukan saja mengerti, tetapi juga dapat menerapkan dalam kehidupan nyata (Abruscato, 2000).

Kehadiran alat-alat peraga sangat membantu para guru dalam pembelajaran IPA (Munandar, 2016). Kebanyakan sekolah-sekolah di Pesawaran sudah mempunyai laboratorium dengan berbagai alat peraga, yaitu alat peraga KIT, dan alat-alat ukur berbagai besaran fisis. KIT IPA yang ada di sekolah-sekolah hanya sebagian kecil saja yang dimanfaatkan dalam proses pembelajaran. Hal yang sama juga terjadi pada alat-alat peraga yang lain, yaitu alat-alat ukur. Hal ini disebabkan karena kebanyakan guru-guru kurang mampu cara menggunakannya. 
Faktor lain yang menyebabkan keadaan ini adalah karena pengelolaan laboratorium yang tidak berjalan. Dengan demikian, tujuan kegiatan pelatihan ini adalah untuk : (1) meningkatkan kemampuan guru-guru IPA SMP/MTs se-Kota Bandar Lampung dalam mengoperasikan alat peraga laboratorium, (2) meningkatkan kemampuan guru-guru IPA SMP/MTs se-Kota Bandar Lampung dalam pengelolaan laboratorium IPA. Melihat kondisi ini maka kegiatan pelatihan pengelolaan laboratorium dan penggunaan alat peraga IPA untuk guru-guru IPA di SMP/MTs se-Kota Bandar Lampung mutlak diperlukan.

\section{SOLUSI/TEKNOLOGI}

Solusi untuk menghadapi permasalahan yang dihadapi dengan menerapkan strategi kontekstual, yaitu mengaitkan antara teori dengan praktik yang disampaikan dengan metoda praktik terbimbing yaitu sistem pengajaran yang berorientasi pada pemecahan masalah yang dihadapi sebagian besar guru-guru SMP se-Kota Bandar Lampung, dan belajar mengenai pengelolaan laboratorium. Pelaksanaan kegiatan pelatihan ini bertempat di SMP Negeri 2 Bandar Lampung, yang dilaksanakan selama 4 hari (32 jam) pada bulan Mei. Subjek pada kegiatan pelatihan ini sebnayak 75 orang guru pada mata pelajaran IPA SMP/MTs se-Kota Bandar Lampung.

Guru IPA memerlukan pemahaman ilmu IPA secara utuh, artinya seorang guru IPA harus memahami fokus dari suatu objek, dan bahasa yang digunakan untuk mengungkap peristiwa alam tersebut. Meenyangkut hal ini, hampir semua guru IPA dapat melaksanakan dengan baik karena hanya memerlukan kemampuan teoritis saja. Namun demikian, seorang guru IPA harus dilengkapi kemampuan menggunakan alat-alat pratikum untuk membuktikan peristiwa alam tersebut sehingga ada kesesuaian antara teori dan kenyataan. Sebagian besar guru-guru IPA SMP Pesawaran tidak terampil mengoperasikan alatalat laboratorium dan mengelola laboratorium.

Perubahan pengetahuan dan ketrampilan sebagai hasil pelatihan diharapkan dapat memacu perubahan perilaku guru-guru IPA dalam membelajarkan materi IPA di SMP/MTs sehingga kualitas lulusan SMP dapat ditingkatkan dan pada akhirnya lulusan SMP dapat menerapkan keilmuannya dalam bentuk nyata (Tahir, 2011). Adapun matrik kegiatan dalam rangka pemecahan masalah dirumuskan dalam Tabel 1.

Evaluasi akan dilakukan pada awal kegiatan dilakukan pre-test untuk mengetahui sejauh mana kemampuan peserta pelatihan tentang materi IPA (Nazir, 2005), kemampuan penggunaan KIT IPA, kemampuan penggunaan alat-alat ukur besaran fisika dan biologi (KIT) serta pemahaman mengenai pengelolaan laboratorium. Akhir kegiatan dilakukan post test, berisikan pertanyaan yang sama dengan tes awal, untuk mengetahui tingkat keberhasilan dan pemahaman guru IPA se-Bandar Lampung. Soal pre test dan post test terdiri atas 8 pertanyaan yaitu:

Tabel 1. Pelatihan Pengelolaan Laboratorium dan Penggunaan Alat Laboratorium IPA.

Kondisi saat ini $\quad$ Perlakuan yang diberikan Kondisi yang diharapkan

- Kurangnya pengetahuan para - Pelatihan pengoperasian alat- - Meningkatnya pengetahuan para guru mengenai pengoperasian alat-alat ukur dan KIT

- Kurangnya pengetahuan para guru mengenai pengoperasian dan mendesain alat biologi

- Kurangnya pemahaman guru IPA dalam mengelola laboratorium alat ukur. Guru dibagi dalam beberapa kelompok, dengan sistem rolling.

- Pelatihan pengoperasian alat KIT. Guru-guru dibagi dalam beberapa kelompok, dengan sistem rolling.

- Sosialisasi tentang pengelolaan laboratorium guru mengenai pengoperasian alat-alat ukur dan KIT

- Meningkatnya pengetahuan para guru mengenai pengoperasian dan mendesain alat biologi

- Meningkatnya pengetahuan para guru mengenai pengelolaan laboratorium 
1. Apakah syarat bagi laboratorium yang baik di sekolah?

2. Sudahkan sekolah bapak/ibu melakukan managemen dan invertarisasi laboratorium?

3. Bagaimana teknik melakukan inventarisasi alat, bahan dan kelengkapan lab lainnya? (berikan contoh bentuk inventarisasi?

4. Disajikan respirometer dan insekta. Dapatkah saudara laju pernafasan hewan tersebut dengan menggunakan alat sediaan!

5. Disediakan alat laboratorium dan tanaman Sprirogyra sp. berkaitan dengan uji fotosintesis. Dapatkah saudara merangkai percobaan ini menjadi rangkaian untuk menganalisis hasil produk fotosintesis!

6. Disedikan alat mikrometer skrup dan kawat. Dapatkah saudara menghitung diameter kawat dengan alat sediaan.

7. Disediakan alat jangka sorong dan sebuah cincin perak. Dapatkah saudara mengukur diameter dalam dan luar dari cincin perak dengan menggunakan alat sediaan!

8. Disediakan KIT Listrik dan magnet. Dapatkah saudara menrangkai sediaan untuk menunjukan percobaan Oersted, percobaan Lorentz, rangkaian seri, rangkaian paralel.

Khalayak sasaran adalah guru-guru IPA SMP/ MTs se-Kota Bandar Lampung yang tergabung dalam Musyawarah Guru Mata Pelajaran IPA Kota Bandar Lampung. Masalah kualitas pembelajaran IPA di Kota Bandar Lampung dan di Indonesia pada umumnya bukan hanya tugas guru itu semata, melainkan masalah yang juga dipikul bersama baik oleh pemerintah kabupaten, pihak sekolah, dan perguruan tinggi sebagai produsen tenaga pendidik. Perguruan tinggi dalam hal ini FKIP Universitas Lampung sebagai salah satu pencetak tenaga pendidik memiliki tanggung jawab moral terhadap kompetensi guru-guru di lapangan. Dengan demikian, kerjasama dari ketiga pihak tersebut secara kelembagaan perlu diwujudkan agar mampu

mengatasi dan meminimalisir permasalahan pendidikan yang makin beragam

\section{HASIL DAN DISKUSI}

Data yang dikumpulkan berupa hasil tes awal, tes akhir, evaluai kerja praktik laboratotium serta evaluasi kerja kelompok. Data analisis pre test dan pos test disajikan pada Tabel 2. Tabel 2 menggambarkan penguasaan substansi pengelolaan laboratorium guru mata pelajaran IPA secara menyeluruh.

Tabel 2. Kemampuan guru IPA dalam managemen laboratorium sekolah

\begin{tabular}{|c|c|c|c|}
\hline \multirow{2}{*}{ Peserta } & \multicolumn{3}{|c|}{ Nilai } \\
\cline { 2 - 4 } & Pre Test & Post test & $\begin{array}{c}\text { Peningkatan } \\
(\%)\end{array}$ \\
\hline 1 & 45.83 & 87.5 & 41.67 \\
\hline 2 & 50 & 83.33 & 33.33 \\
\hline 3 & 45.83 & 83.33 & 37.50 \\
\hline 4 & 62.5 & 66.67 & 4.17 \\
\hline 5 & 66.67 & 87.5 & 20.83 \\
\hline 6 & 45.83 & 79.17 & 33.33 \\
\hline 7 & 45.83 & 66.67 & 20.83 \\
\hline 8 & 41.67 & 66.67 & 25.00 \\
\hline 9 & 54.17 & 83.33 & 29.17 \\
\hline 10 & 66.67 & 79.17 & 12.50 \\
\hline 11 & 54.17 & 79.17 & 25.00 \\
\hline 12 & 50 & 87.5 & 37.50 \\
\hline 13 & 50 & 83.33 & 33.33 \\
\hline 14 & 0 & 66.67 & 66.67 \\
\hline 15 & 41.67 & 83.33 & 41.67 \\
\hline 16 & 66.67 & 87.5 & 20.83 \\
\hline 17 & 50 & 100 & 50.00 \\
\hline 18 & 41.67 & 75 & 33.33 \\
\hline 19 & 45.83 & 79.17 & 33.33 \\
\hline 20 & 58.33 & 95.83 & 37.50 \\
\hline 21 & 54.17 & 83.33 & 29.17 \\
\hline
\end{tabular}




\begin{tabular}{|c|c|c|c|c|c|c|c|}
\hline \multirow[b]{2}{*}{ Peserta } & \multicolumn{3}{|c|}{ Nilai } & \multirow[b]{2}{*}{ Peserta } & \multicolumn{3}{|c|}{ Nilai } \\
\hline & Pre Test & Post test & $\begin{array}{c}\text { Peningkatan } \\
(\%)\end{array}$ & & Pre Test & Post test & $\begin{array}{c}\text { Peningkatan } \\
(\%)\end{array}$ \\
\hline 22 & 54.17 & 75 & 20.83 & 60 & 37.5 & 83.33 & 45.83 \\
\hline 23 & 62.5 & 83.33 & 20.83 & 61 & 45.83 & 0 & -45.83 \\
\hline 24 & 54.17 & 91.67 & 37.50 & 62 & 0 & 91.67 & 91.67 \\
\hline 25 & 50 & 87.5 & 37.50 & 63 & 37.5 & 83.33 & 45.83 \\
\hline 26 & 0 & 87.5 & 87.50 & 64 & 50 & 70.83 & 20.83 \\
\hline 27 & 54.17 & 79.17 & 25.00 & 65 & 62.5 & 87.5 & 25.00 \\
\hline 28 & 66.67 & 87.5 & 20.83 & 66 & 66.67 & 83.33 & 16.67 \\
\hline 29 & 54.17 & 83.33 & 29.17 & 67 & 58.33 & 79.17 & 20.83 \\
\hline 30 & 45.83 & 91.67 & 45.83 & 68 & 58.33 & 75 & 16.67 \\
\hline 31 & 41.67 & 75 & 33.33 & 69 & 58.33 & 79.17 & 20.83 \\
\hline 32 & 37.5 & 83.33 & 45.83 & 70 & 50 & 70.83 & 20.83 \\
\hline 33 & 0 & 54.17 & 54.17 & 71 & 66.67 & 75 & 8.33 \\
\hline 34 & 45.83 & 91.67 & 45.83 & 72 & 58.33 & 75 & 16.67 \\
\hline 35 & 54.17 & 83.33 & 29.17 & 73 & 45.83 & 87.5 & 41.67 \\
\hline 36 & 33.33 & 62.5 & 29.17 & 74 & 54.17 & 79.17 & 25.00 \\
\hline 37 & 50 & 83.33 & 33.33 & 75 & 58.33 & 79.17 & 20.83 \\
\hline
\end{tabular}

\begin{tabular}{|c|c|c|c|c|}
\hline 38 & 50 & 83.33 & 33.33 & \\
\hline 39 & 58.33 & 70.83 & 12.50 & Tabel 2 menunjukan bahwa sebaran. \\
\hline 40 & 54.17 & 100 & 45.83 & pemahaman mengenal \\
\hline 41 & 58.33 & 83.33 & 25.00 & guru bernilai sangat fluktuatif. Hasil analisis \\
\hline 42 & 54.17 & 66.67 & 12.50 & nenunjukan bahwa penguaswaan meteri \\
\hline 43 & 58.33 & 79.17 & 20.83 & pengelolaan laboatorium guru sangat \\
\hline 44 & 41.67 & 70.83 & 29.17 & Pada kolom nilai tes awal Tabel \\
\hline 45 & 0 & 66.67 & 66.67 & dru dalam managerial laboratorium \\
\hline 46 & 41.67 & 70.83 & 29.17 & berkatagori rendah. Dimana nilai standar \\
\hline 47 & 62.5 & 83.33 & 20.83 & ketuntasan benilai $\geq 70$. peningkatan \\
\hline 48 & 50 & 75 & 25.00 & kemampuan guru dalam tata pengelolaan \\
\hline 49 & 33.33 & 79.17 & 45.83 & . 10 \\
\hline 50 & 54.17 & 70.83 & 16.67 & klisaran $20 \%$ sampai dengan $29.9 \%$ : \\
\hline 51 & 62.5 & 79.17 & 16.67 & pleningkatan $>50 \%$ hanya berindeks \\
\hline 52 & 58.33 & 100 & 41.67 & 1 1,20\%. Peningkatan ini dapat dijadikan \\
\hline 53 & 66.67 & 87.5 & 20.83 & kegiatan pelatihan ini \\
\hline 54 & 0 & 75 & 75.00 & Themberikan dampak pada penambahan \\
\hline 55 & 37.5 & 79.17 & 41.67 & $2(010)$. \\
\hline 56 & 54.17 & 87.5 & 33.33 & Kemampuan guru dalam melalukan \\
\hline 57 & 50 & 87.5 & 37.50 & iatan praktikum berkriteria rendah ketika \\
\hline 58 & 50 & 87.5 & 37.50 & ukan . Hanya $10,67 \%$ (Tabel \\
\hline 59 & 45.83 & 83.33 & 37.50 & nelakukan kiegiatan praktikum. Standar \\
\hline
\end{tabular}


kegiatan praktikum adalah $\geq 70$. Rendahnya kemampuan melakukan praktikum dilatarbelakangi oleh rendahnya pengetahuan peserta dalam implementasi pelaksanaan praktikum yang sesuai dengan pembelajaran IPA pada jenjang SMP. Namun, melalui kegiatan ini perlahan peserta memahami secara fungsional tujuan kegiatan praktikum yang dilatihkan.

Tabel 3. Nilai Kegiatan Praktikum

\begin{tabular}{|c|c|c|c|c|}
\hline \multirow[b]{2}{*}{ No } & \multirow[b]{2}{*}{ Nilai } & \multicolumn{2}{|c|}{ Jumlah Peserta } & \multirow{2}{*}{$\begin{array}{c}\text { Persentase } \\
\text { Tuntas } \\
(\%)\end{array}$} \\
\hline & & $\begin{array}{c}0 \text { s.d. } \leq \\
69,9\end{array}$ & $\begin{array}{c}\geq 70 \text { s.d. } \\
100\end{array}$ & \\
\hline 1 & Pre-test & 67 & 8 & $10,6 \%$ \\
\hline 2 & $\begin{array}{l}\text { Post- } \\
\text { test }\end{array}$ & 0 & 75 & 100 \\
\hline
\end{tabular}

Hasil penilaian penggunaan alat peraga secara spesifik telihat pada Tabel 4.

Tabel 4. Kemampuan guru menggunakan alat peraga (Kit) IPA

\begin{tabular}{|c|c|c|c|}
\hline No & Nilai & Jumlah & $\begin{array}{l}\text { Persentase } \\
\text { Tuntas (\%) }\end{array}$ \\
\hline 1 & $0-69,9$ & 0 & 0 \\
\hline 2 & $70-79,9$ & 31 & 41,33 \\
\hline 3 & $80-89,9$ & 32 & 42,67 \\
\hline 4 & $90-100$ & 12 & 16,00 \\
\hline
\end{tabular}

peserta setelah mengikuti kegiatan pelatihan secara terperinci terlihat pada Tabel 4. Secara nyata terlihat adanya peningkatan kinerja guru keterampilan dalam menggunakan dan merancang alat laboratorium. Kedua kegiatan ini menunjukan respon positif pada seluruh peserta dalam kegiatan ini. Terlihat adanya peningkatan jumlah peserta selama kegiatan berlangsung. Seluruh peserta yaitu guruguru SMP se-Bandar Lampung bersifat antusias terhadap kegiatan ini. Adanya peningkatan kemampuan peserta ditunjukkan pada peningkatan kemampuan kognitif dan psikomotor dalam menjawab soal-soal pretes dan postes.

Keterampilan pengelolaan laboratorium berkontribusi terhadap efektivitas proses pembelajaran (Novianti, 2011; Peniati, 2013). Hal ini menunjukan bahwa pemahaman guru-guru IPA se-
Bandar Lampung mengenai penguasaan terhadap managemen Laboratorium bagi guru IPA wajib dilakukan (Pusat Kurikulum, 2013).

Fokus pada kemampuan professional guru sebelum mengikuti pelatihan adalah sebagai berikut:

1. Pengetahuan tata kelola laboratorium bagi peserta sebagian besar belum memahaminya.

2. Standar keselamatan kerja laboratorium sekolah, peserta belum mengetahuinya bahkan hanya $13,2 \%$ yang menguasai.

3. Standar Penggunaan dan penyimpanan alat laboratorium bagi peserta sudah cukup memahaminya, 52\% guru telah menguasai.

Kondisi setelah pelatihan:

1. Tidak ada peserta yang menyatakan ketidak tahuan pada aspek yang tidak tahu

2. Sebagian besar peserta mengalami peningkatan kemampuan pada setiap aspek

3. Peserta mengungkapkan adanya manfaat yang diperoleh melalui kegiatan ini karena adanya peningkatan keluasan materi yang diperoleh bagi seluruh peserta

Secara umum kemampuan managerial yang telah dilakukan menunjukan respon positif bagi peserta. Begitupula dengan kemampuan peserta menggunakan kit/alat peraga IPA. peserta sudah mampu menggunakan alat peraga dengan baik, hanya saja kemampuan analitik peserta dalam mengintepretasikan hasil penggunaan alat peraga belum menunjukan prestasi yang baik. Gambar 1 sampai dengan Gambar 5 menunjukan proses kegiatan pelatihan.

Seluruh peserta telah mengenal macam alat peraga IPA yang digunakan bagi siswa SMP. Begitu pula dengan kegiatan praktikum (biologi) sebagian peserta telah mengenal kegiatan praktikum. Pemahaman mengenai fungsi kegiatan setiap praktikum sebagian peserta belum memiliki pemahaman secara keseluruhan. Melalui 
bimbingan selama pelatihan peserta mengalami peningkatan pemahaman mengenai kegiatan praktikum. Peningkatan itu ditunjukan dengan kemampuan menjawab pertanyaan secara lisan, serta mampu menjelaskan secara terpierinci fungsi dan tujuan dari setiap kegiatan praktikum. Efektivitas penggunaan laboratorium oleh guru yang diimplikasikan dalam kegiatan pembelajaran IPA sangat berpengaruh terhahap penguasaan konsep dan peningkatan hasil belajar (Putri, 2014). Dengan demikian diadakannya pelatihan ini mengahsilkan hasil yang positif terhadap peningkatan pengetahuan guru-guru IPA SMP se-kota Bandar Lampung yang pada akhirnya berimplikasi pada peningkatan dan kualitas mutu pendidikan (Putra dan Sudargo, 2014; Reiss, 2012).

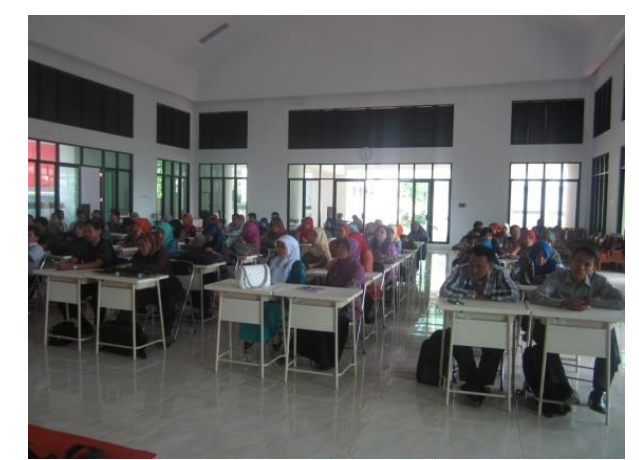

Gambar 1. Peserta kegiatan pelatihan

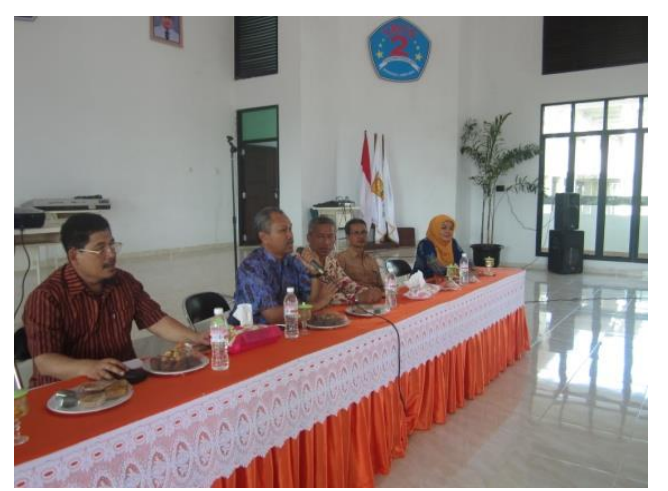

Gambar 2. Pembukaan kegiatan pelatihan

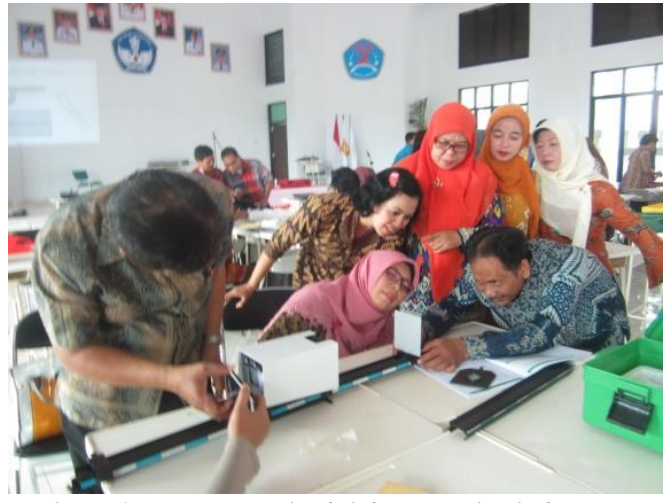

Gambar 3. Merangkai kit pembelajaran IPA

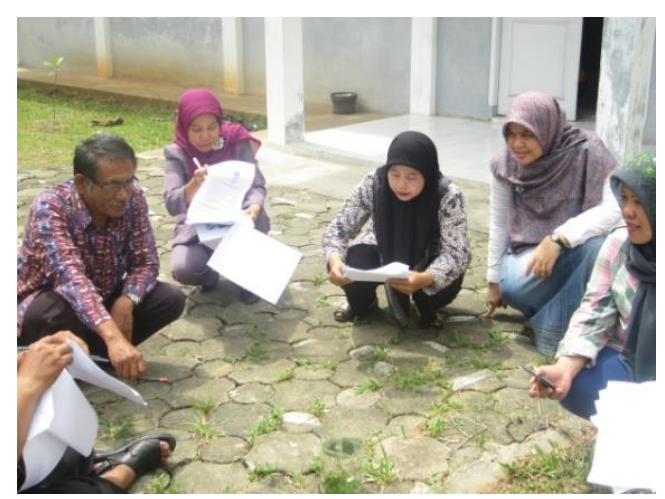

Gambar 4. Mengamati reaksi kegiatan praktikum

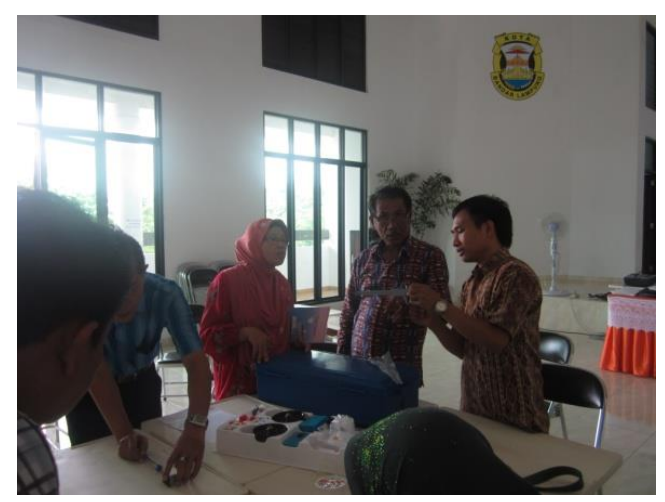

Gambar 5. Kegiatan praktikum IPA

\section{KESIMPULAN}

Kegiatan pelatihan pengelolaan laboratorium, alat peraga dan perangkat KIT IPA bagu guru SMP/MTs se Kota Bandar Lampung memberikah hasil terhadap peningkatan kemampuan guru dalam Tata Kelola Laboratorium. Seluruh peserta telah mengenal perangkat/kit IPA dan secara gradual mengalami peningkatan dalam penggunaannya. Secara keseluruhan guru 
sudah mampu mengenal fungsi dan kegunaan alat dan bahan praktikum.

\section{UCAPAN TERIMA KASIH}

Penulis mengucapkan terimakasih sebesar-besarnya kepada pendanaan DIPA, Fakultas FKIP Universitas Lampung atas dukungan dana yang diberikan pada kegiatan pelatihan ini, serta kepada seluruh anggota MGMP IPA Kota Bandar Lampung atas kerjasama dan fasilitas yang telah diberikan

\section{PUSTAKA}

Abruscato, J. 2000. Teaching Children Science: A Discovery Approach. New Jersey: Person Education Company.

Anonim. 2014. Pelatihan Guru. (http://yantisitorus.wordpress.com/tag/ kompetensi/, Diakses 10 Juli 2019)

Daryanto. 2014. Pendekatan Pembelajaran Saintifik Kurikulum 2013. Yogyakarta: Gaya Media.

Depdiknas. 2007. Peraturan Menteri Pendidikan Nasional Republik Indonesia Nomor 24 Tahun 2007 Tentang Standar Sarana Dan Prasarana Untuk Sekolah Dasar/ Madrasah Ibtidaiyah (SD/MI), Sekolah Menengah Pertama/Madrasah Tsanawiyah (SMP/MTS), dan Sekoah Menengah Atas/Madrasah Aliyah (SMA/MA). Jakarta: Depdiknas.

Direktorat Jendral Pendidikan Dasar dan Menengah Umum. 2003. Ketentuan Umum Pendidikan Pra Sekolah, Dasar, Dan Menengah Umum. Depdiknas. Jakarta.

Khamidah, N. dan N. Aprilia. 2014. Evaluasi Program Pelaksanaan Praktikum Biologi Kelas XI SMA SeKecamatan Umbulharjo Yogyakarta Semester II Tahun Ajaran 2013/2014.
Jupemasi Pbio 1(1): 5-8. (https://www.researchgate.net/283506 279_Evaluasi_Program_Pelaksanaan_ Praktikum, diakses tanggal 18 September 2019).

Litasari, K. N., N. Setiati, dan L. Herlina. 2014. Profil Pembe-lajaran Biologi Berbasis Praktikum dan Implikasinya Terhadap Hasil Belajar Siwa di SMA Negeri se-Kabupaten Semarang. Unnes Journal of Biology Education 3(1): (https://de.scribd.com/document/3325 98 343/4457-1-9153-2- 10-20160 325, diakses tanggal 19 Septrmber 2019).

Maulina, D. 2008. Profil Kemampuan GuruGuru IPA SMP se-Bandar Lampung dalam Melakukan Kegiatan Praktikum. Jurnal Pendidikan Biologi Universitas Lampung. (https://jurnal.fkip.unila.ac.id/index.ph p/JBT/article/view/5850, diakses tanggal 15 Juli 2019)

Munandar, K. 2016. Pengenalan Laboratorium IPA-Biologi Sekolah. Bandung: PT Refika Aditama.

Nazir, M. 2005. Metode Penelitian. Bogor: Ghalia Indonesia.

Novianti, R. N. 2011. ISSN. Kontribusi Pengelolaan Laboratorium dan MotivasiBelajar Siswa Terhadap Efektivitas Proses Pembelajaran. No. 1, hal. $158-166$.

Peniati, E. 2013. Model Analisis Evaluasi Diri untuk Mengembangkan Kemampuan Mahasiswa Calon Guru IPA dalam Merancang Pengembangan Laboratorium di Sekolah.Jurnal Pendidikan IPA Indonesia.2(2):107119

Pusat Kurikulum. 2013. Kurikulum 2013 Kompetensi Dasar SMP/MTs. Jakarta : 
Kementerian Pendidikan dan Subiantoro, A. 2010. Pentingnya Praktikum Kebudayaan. dalam Pembelajaran IPA. (http://staff.uny.ac.id/sites/default/files

Putra, R. A. dan F. Sudargo. 2014. The /tmp/.pdf, diakses 25 Juli 2019). effect of program laboratory inquiry practicum based (PPZI-BIL) to mastering invertebrate zoology concept. 86 Journal of Education and Practice Vol 5 No. 36 ISSN 22221735: 121-125.

Putri, H. P. 2014. Skripsi Pengaruh Metode Praktikum disertai Resitasi Terhadap Minat dan Hasil Belajar Biologi Siswa di MA Wahid Hasyim Yogyakarta. Universitas Islam Negeri Sunan Kalijaga. Yogyakarta.

Reiss, A. 2012. Effectiveness of practical work. Journal of Research in Science Teaching: 1-24.

Sudarwan. 2002. Inovasi Pendidikan. Jakarta: Bheineka.

Sutrisno, W. 2007. Pemeliharaan Fasilitas Laboratorium Fisika untuk Diklat Teknisi Laboratorium. Bandung: Pusat Pengembangan dan Pemberdayaan Pendidik dan Tenaga Kependidikan IPA.

Suyanta. 2010. Manajemen Operasional Laboratorium. Yogyakarta: Jurusan Pendidikan Kimia FMIPA Universitas Negeri Yogyakarta.

Tahir, M. 2011. Pengantar Metodologi Penelitian Pendidikan. Makassar: Universitas Muhammadiyah Makassar.

Yuliati. 2010. Jenis-Jenis Bahaya di Laboratorium dan Pencegahannya. Laporan PPM. Yogyakarta: Universitas Negeri Yogyakarta. 